\title{
PENGARUH PENDEKATAN PEMBELAJARAN KONTEKSTUAL TERHADAP HASIL BELAJAR SISWA PADA MATERI POKOK FLUIDA DINAMIS SEMESTER GENAP KELAS XI SMA NEGERI 9 MEDAN T.P 2012/2013
}

\author{
Rappel Situmorang dan Ladestam Sitinjak \\ Jurusan Fisika FMIPA Universitas Negeri Medan \\ rappel.situmorang@gmail.com
}

\begin{abstract}
ABSTRAK
Penelitian ini bertujuan untuk mengetahui ada tidaknya Pengaruh pendekatan pembelajaran kontekstual terhadap hasil belajar siswa pada materi pokok Fluida Dinamis di Semester Genap kelas XI SMA Negeri 9 Medan Tahun Pelajaran 2012/2013. Jenis penelitian ini adalah quasi eksperimen. Populasi dalam penelitian adalah seluruh siswa kelas XI IPA Semester II SMA Negeri 9 Medan T.P 2012/2013 yang terdiri dari 3 kelas berjumlah 102 orang. Pengambilan sampel dilakukan dengan cara cluster random sampling dengan mengambil 2 kelas dari 3 kelas secara acak yaitu kelas XI IPA-1 sebagai kelas eksperimen yang berjumlah 34 orang dan kelas XI IPA-2 sebagai kelas kontrol yang berjumlah 34 orang. Diberikan perlakuan yang berbeda, kelas eksperimen dengan pendekatan pembelajaran kontekstual dan kelas kontrol dengan pembelajaran konvensional. Dari pengolahan data postes diperoleh bahwa ada pengaruh peningkatan hasil belajar dengan menggunakan pendekatan pembelajaran kontekstual terhadap hasil belajar siswa pada materi pokok fluida dinamis di kelas XI IPA semester genap SMA Negeri 9 Medan Tahun Pelajaran $2012 / 2013$.
\end{abstract}

Kata Kunci : Pendekatan kontekstual, Hasil belajar

\section{PENDAHULUAN}

Sumber daya manusia yang berkualitas sudah pasti didukung oleh pendidikan yang berkualitas juga. Misi pendidikan yang seutuhnya menjadi tang-gung jawab profesional setiap guru harus dapat berupaya meningkatkan kualitas sekaligus mencerdaskan kehidupan bangsa. Guru dalam hal ini berperan dalam proses kegiatan pembelajaran sebagai kegiatan dalam mencapai tujuan pendidikan. Hal ini berarti berhasil tidaknya tujuan pendidikan bergantung pada bagaimana proses belajar yang dialami oleh siswa sebagai peseta didik dan guru sebagai tenaga pendidik yang tidak hanya berupaya mengusai materi pembelajaran namun juga mengetahui bagaimana cara materi itu disampaikan dan bagaimana pula karakteristik siswa yang menerima materi pelajaran tersebut (Sagala, S, 2005).

Guru sebagai tenaga pendidik diharapkan mampu mengelola 
pendekatan pembelajaran yang sesuai dengan karakter seluruh siswa sebagai pendekatan pembelajaran. Karakter siswa yang sesuai dengan pendekatan pembelajaran tersebut menyebabkan suasana belajar akan tampak lebih menarik, khususnya pembelajaran fisika disekolah.

Fisika merupakan pelajaran yang cukup menarik sebab dapat diamati dari gejala-gejala alam dan fenomena-fenomena yang terjadi dalam kehidupan sehari-hari. Namun jika dilihat dari hasil belajar peserta didik, ternyata fisika termasuk dalam nilai rendah dibanding nilai pelajaran yang lainnya.

Berdasarkan hasil wawancara peneliti dengan guru bidang studi fisika di SMA Negeri 9 Medan, menyebutkan bahwa nilai rata-rata yang diperoleh pada mata pelajaran fisika di kelas XI IPA pada materi pokok Fluida dinamis mencapai 60 . Ini dapat dilihat dari nilai ulangan harian siswa. Sedangkan syarat ketuntasan belajar di sekolah tersebut adalah nilai 65 .

Rendahnya nilai fisika yang diperoleh oleh siswa tadi dipengaruhi oleh kurang efektifnya pembelajaran yang di-gunakan oleh guru, pembelajarannya tampak monoton dari waktu kewaktu, hal ini tampak dari pengajaran yang dominan dan berpusat pada guru. Selain itu kekurangan efektifan pendekatan pembelajaran ini menimbulkan kejenuhan dan kebosanan dalam diri siswa yang ber-dampak pada gagalnya guru dalam menyampaikan materi pembelajaran. Pendekatan pengajaran yang kurang bervariasi juga menjadi alasan mengapa pelajaran fisika menjadi pelajaran yang tampak monoton bagi siswa, apalagi ketika diberikan soal kebanyakan siswa tidak mengerti membaca soal dan menentukan rumus apa yang dipakai dan yang terpenting siswa merasa fisika itu kurang penting bagi mereka, hal ini disebabkan ketidakmampuan siswa untuk mengaitkan materi pelajaan yang ia terima dengan kehidupan sehari-hari (Sanjaya, W, 2006).

Faktor yang terdapat didalam diri siswa seperti sikap mereka terhadap fisika juga mempengaruhi rendahnya nilai fisika, dimana mereka beranggapan bahwa pelajaran fisika lebih sulit dari pelajaran lainnya, sehingga siswa lebih dahulu merasa jenuh sebelum mempelajarinya atau kurangnya motivasi siswa, anggapan ini sesuai dengan pernyataan siswa yang mengatakan terlalu banyak rumus sehingga menyulitkan siswa untuk mengingat rumus-rumus tersebut, inilah merupakan sifat negatif yang menyebabkan dorongan untuk belajar lebih giat akan menjadi rendah, sehingga siswa menjadi pasif. Ini dapat diketahui dari hasil wawancara oleh penulis selama melaksanakan observasi di sekolah SMA Negeri 9 Medan.

Kegiatan pembelajaran dapat berhasil jika guru sebagai pengajar harus mampu marancang teknik pembelajaran yang sesuai dengan menggunakan pendekatan dan metode pembelajaran yang bervariasi sehingga kegiatan pembelajaran menjadi lebih menarik dan tidak membosankan (Slameto, 2010).

Pembelajarandan pengajaran kontekstual, sebagai sebuah sistem mengajar, didasarkan pada pikiran bahwa makna muncul dari hubungan antara isi dan konteksnya 
(Johnson, E.B, 2007). Konteks memberikan makna pada isi. Semakin banyak keterkaitan yang ditemukan siswa dalam suatu konteks yang luas, semakin banyak bermaknalah isinya bagi mereka. Jadi,sebagian besar tugas seorang guru adalah menyediakan konteks. Semakin mampu para siswa mengaitkan pelajaran-pelajaran akademis mereka dengan konteks ini, semakin banyak makna yang akan mereka dapatkan dari pelajaran tersebut.

Penelitian lainnya dilakukan oleh Zendrato (2011) pada hasil penelitiannya menyebutkan bahwa pembelajaran dengan Pendekatan kontekstual dapat meningkatkan hasil belajar siswa yang dapat dilihat dari nilai rata-rata postes hasil belajar fisika pada kelas eksperimen. Menggunakan pendekatan kontekstual yakni nilai rata-rata 71,05 sementara pada kelas konvensional diperoleh nilai rata-rata postesnya 65,81. Dalam kelaskontekstual, tugas guru adalah membantu siswa mencapai tujuannya. Maksudnya, guru lebih banyak berurusan dengan pendekatan daripada memberi informasi. Tugas guru mengelola kelas sebagai sebuah tim yang bekerja bersama untuk menemukan sesuatu yang baru bagi anggota kelassiswa. Sesuatu yang baru datang dari menemukan sendiri bukan dari apa kata guru. Begitulah peran guru dikelas yang dikelola dengan pendekatan kontekstual.

Penelitian ini juga didukung oleh asrina (2010) yang menyebutkanbahwa adanya pengaruh yang signifikan pada penggunaan pendekatan pembelajaran kontekstual terhadap hasil belajar fisika siswa pada materi pokok zat dan wujudnya, ini dapat dilihat dari nilai rata-rata postes hasil belajar fisika pada kelas eksperimen yang menggunakan pendekatan kontekstual lebih tinggi jika dibandingkan pada kelas konvensional.

Penelitian ini belum mencapai hasil yang maksimal karena dalam penelitian ini penggunaan pendekatan oleh peneliti khususnya masyarakat belajar dalam pem-bagian kelompok, peneliti terlalu banyak membagi jumlah kelompok sehingga waktu yang tersedia menjadi tidak efisien, selain itu peneliti masih kurang menggunakan media sehingga setiap kelompok tidak dapat bekerja secara maksimal.

Penelitian ini juga belum mencapai mencapai hasil yang maksimal karena disebabkan oleh beberapa faktor, diantaranya adalah kurang aktifnya siswa dalam proses pembelajaran danpengalokasian waktu yang kurang efisien. Pada penelitian ini penulis berusaha mengatasi kendala-kendala yang ada dengan cara menggunakan media pembelajaran yang sederhana, menciptakan suasana yang lebih efektif yaitu dengan cara melakukan pemantauan pada setiap siswa ketika proses eksperimen sedang berlangsung dan lebih memotivasi siswa serta lebih mengoptimalkan alokasi waktu untuk setiap tahap pembelajaran yang sudah ditetapkan dalam rencana pelaksanaan pembelajaran, sehingga alokasi waktu untuk setiap tahappembelajaran efisien.

Pendekatan pembelajaran konteks-tual dapat merangsang dan memacu semangat siswa untuk lebih aktif dalam proses belajar mengajar dan dapat merangsang 
pemikiran siswa lewat komponen kontruktivisme yang ada di dalam pende-katan pembelajaran kontekstual serta dapat menambah pengalaman dan pengetahuan siswa akan konsep-konsep fisika dalam kehidupan sehari-hari sehingga pem-belajaran dirasakan lebih bermakna (Johnson, E.B, 2007).

Berdasarkan

uraian

pernyataan diatas, penulis tertarik untuk melaksanakan penelitian dengan judul: Pengaruh Pendekatan Pembelajaran

Kontekstual

Terhadap Hasil Belajar Siswa Pada Materi Pokok Fluida Dinamis Semester Genap Kelas XI SMA N 9 Medan T.P 2012/2013.

\section{METODE PENELITIAN}

Penelitian ini dilaksanakan di SMA Negeri 9 Medan jalan Bukit Barisan Labuhan Deli Medan Labuhan T.P 2012/2013. Penelitian dilaksanakan pada semester genap kelas XI bulan Mei-Juni Tahun Pembelajaran 2012/2013, adapun yang menjadi populasi penelitian adalah seluruh siswa kelas XI IPA SMA Negeri 9 Medan yang terdiri dari 3 kelas paralel masing-masing kelas terdiri dari 34 orang dengan jumlah 102 siswa.

Sampel dalam penelitian ini adalah dua kelas yaitu satu kelas diajarkan dengan menggunakan pembelajaran kontekstual yaitu kelas XI IPA 1 dengan jumlah siswa 34 siswa dan satu kelas lagi diajarkan dengan pembelajaran konvensional yaitu kelas XI IPA 2 dengan jumlah siswa 34 siswa. Pengambilan sampel dalam penelitian ini dilakukan dengan cara cluster random sampling.

Penelitian ini menerapkan dua perlakuan yang berbeda, pada sampel kelompok eksperimen diterapkan

Pendekatan

pembelajaran

kontekstual, kemudian pada kelompok kontrol diterapkan pembelajaran konvensional. Dengan demikian desain penelitiannya seperti pada tabel 3.1.

Desain penelitian yang dipergunakan dengan menerapkan dua perlakuan yang berbeda, pada sampel kelompok eksperimen diterapkan pembelajaran pendekatan kemudian pada kelompok kontrol diterapkan pembelajaran konvensional. Dengan demikian desain penelitiannya seperti pada table 3.1.

Table 3.1

RancanganPenelitianPretesPostes Dua Kelompok ( Two Group Pretes Postes Desaign)

\begin{tabular}{|c|c|c|c|}
\hline Sampel & $\begin{array}{c}\text { Pret } \\
\text { es }\end{array}$ & $\begin{array}{c}\text { Perlaku } \\
\text { an }\end{array}$ & $\begin{array}{c}\text { Poste } \\
\mathrm{s}\end{array}$ \\
\hline $\begin{array}{c}\text { Kelas } \\
\text { eksperimen }\end{array}$ & $\mathrm{T}_{1}$ & $\mathrm{X}_{1}$ & $\mathrm{~T}_{2}$ \\
\hline Kelas Kontrol & $\mathrm{T}_{1}$ & 0 & $\mathrm{~T}_{2}$ \\
\hline
\end{tabular}

Keterangan:

$\mathrm{X}_{1}$ :Pendekatan

Pembelajaran kontekstual

$\mathrm{X}_{2}$ :Pendekatan konvesional

Pembelajaran

T1:Pretes yang diberikan kepada kelas eksperimen dan kelas control sebelum diberikan perlakuan. Tes yang diberikan berupa tes hasil belajar pada materi pokok Fluida

T2:Postes yang diberikan setelah perlakuan kepada kelas eksperimen dan kelas kontrol.

Data yang diperoleh diuji normalitasnya untuk mengetahui data kedua sampel berdistribusi normal digunakan uji Lilliefors. 
Kemudian dilakukan uji homogenitas untuk mengetahui apakah kedua sampel berasal dari populasi yang homogen digunakan uji kesamaan varians. Diperoleh $\mathrm{F}_{\text {hitung }}>\mathrm{F}_{\text {tabel, }}$ maka dapat diambil kesimpulan bahwa kedua sampel tidak mempunyai varians yang homogen dengan $\alpha=0,10$ ( $\alpha$ adalah taraf nyata untuk pengujian). Pengujian hipotesis digunakan uji t.

Kriteria pengujian adalah: terima $\mathrm{H}_{\mathrm{o}}$ jika $-t_{1-(1 / 2) \alpha}<t<t_{1-(1 / 2) \alpha}$ dimana $t_{1-(1 / 2) \alpha}$ didapat dari daftar distribusi t dengan $d k=n_{1}+n_{2}-2$ dan peluang $t_{1-(1 / 2) \alpha}$ dengan $\alpha=0,05$ untuk harga t lainnya $H_{o}$ ditolak.

\section{HASIL PENELITIAN}

Penelitian ini melibatkan dua kelas yang diberikan perlakuan pendekatan pembelajaran yang berbeda. Dimana satu kelas sebagai kelas eksperimen diberikan perlakuan dengan menggunakan. Pendekatan pembelajaran kontekstual dan satu kelas lainnya sebagai kelas control diberikan perlakuan dengan menggunakan konvensional.

Hasil penelitian yang penulis peroleh adalah nilai rata-rata pretes kelas eksperimen sebesar 41,41 dan nilai rata-rata pretes kelas kontrol sebesar 36,71.

Secara lebih terperinci, data nilai pretes kedua kelas tersebut dapat digambarkan seperti pada gambar 4.1 .

\section{Diagram Batang Pretest Kelas Kontrol Dan Eksperimen}

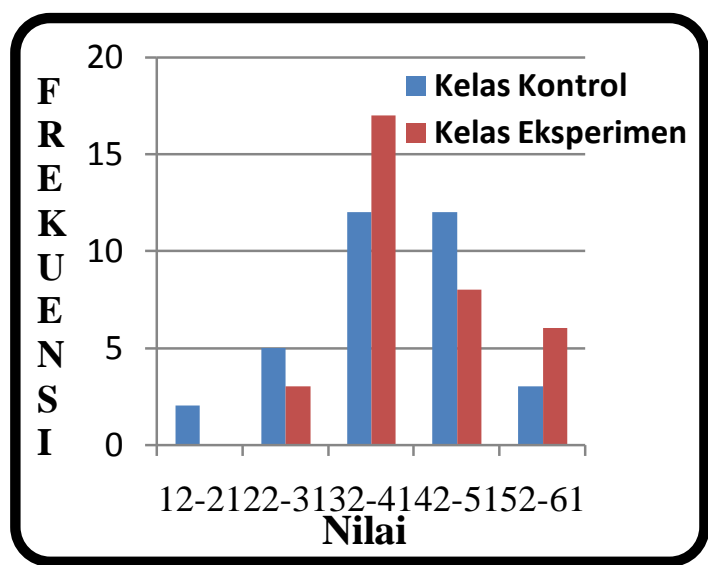

Gambar 4.1.Diagram batang data pretes kelas eksperimen dan kelas kontrol

Berdasarkan hasil pretes yang diperoleh, selanjutnya diberikan perlakuan yang berbeda dimana pada kelas eksperimen di-berikan pembelajaran denganmeng-gunakan pendekatan pembelajaran kontekstual dan pada kelas kontrol diberikan pembelajaran konvensional. Rata-rata postes untuk tiap kelas setelah diberi perlakuan yaitu untuk kelas eksperimen sebesar 72,82 dan ratarata postes kelas kontrol sebesar 68,23 .

Secara lebih terperinci, data nilai postes kedua kelas tersebut dapat digambarkan dalam diagram batang seperti gambar 4.2. 
Diagram Batang Postest Kelas Eksperimen dan Kelas Kontrol

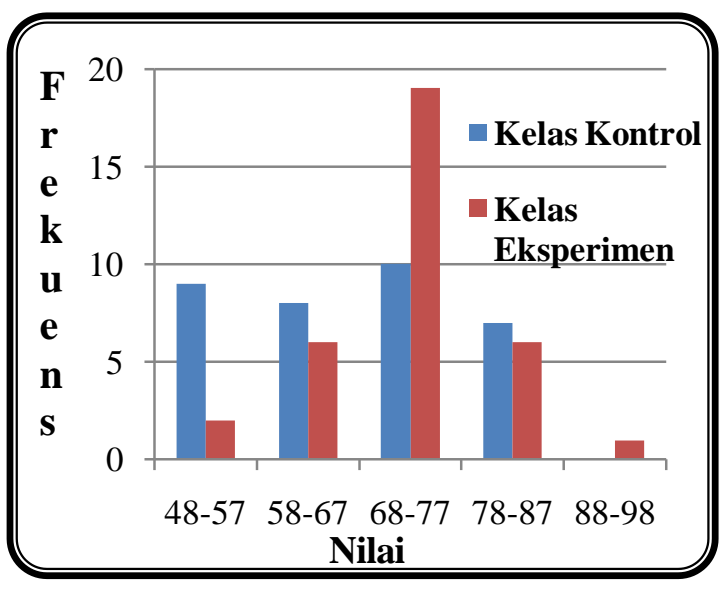

Gambar 4.2. Diagram batang data postes kelas control dan eksperimen

Hasil ini menunjukkan adanya perbedaan antara nilai postes kelas eksperimen lebih tinggi dibandingkan dengan kelas kontrol. Perbedaan peningkatan hasil belajar antara kelas kontrol dengan kelas eksperimen adalah sebesar 6,73 sehingga dapat disimpulkan bahwa ada pengaruh pendekatan pembelajaran kontekstual terhadap hasil belajar siswa kelas XI pada materi pokok Fluda dinamis.

Berdasarkan hasil uji coba normalitas dengan uji Lilliefors data pretes menunjukkan bahwa $\mathrm{L}_{\text {hitung }}<\mathrm{L}_{\text {tabel }}$ dengan $\alpha=0,05$ dapat diartikan data berdistribusi normal. Kelas eksperimen memiliki Lhitung $(0,1478) \quad<\mathrm{L}_{\text {tabel }}(0,1520) . \quad$ Kelas control memiliki Lhitung $(0,1212)<\mathrm{L}^{-}$ tabel $(0,1520)$ sehingga dapat diartikan bahwa data hasil pretes berdistribusi normal. Uji Lilliefors data postes menunjukkan bahwa $\mathrm{L}_{\text {hitung }}<\mathrm{L}_{\text {tabelyaitu0,1308 }}<\quad 0,1520$ untuk kelas eksperimen dan $0,1202<0,1520$ untuk kelas kontrol dengan $\alpha=0,05$ sehingga dapat diartikan bahwa data hasil pretes berdistribusi normal.
Uji

homogenitas menggunakan uji $\mathrm{F}$ untuk data pretes menunjukkan bahwa $\mathrm{F}_{\text {hitung }}<$ $\mathrm{F}_{\text {tabel }}$ yaitu1,394<1,804 dengan $\alpha=$ 0,10, maka diartikan bahwa data pretes homogen. Uji F untuk data postes menunjukkan bahwa $\mathrm{F}_{\text {hitung }}<$ $\mathrm{F}_{\text {tabel }}$ yaitu1,420 $<1,804$ dengan $\alpha=$ 0,10, maka diartikan bahwa data postes homogen.

Uji hipotesis menggunakan uji t, dimaksudkan untuk melihat perbedaan hasil belajar kelas eksperimen dengan kelas kontrol akibat adanya pengaruh penerapan pendekatan pembelajaran kontekstual. Syarat dilakukannya uji $t$ adalah data harus berdistribusi normal dan harus berasal dari populasi yang homogen (Arikunto, S., 2011). Melihat kedua syarat telah dipenuhi, berikut penyajian peng-ujian hipotesis dengan uji $\mathrm{t}$ (satu pihak) dengan $\quad \alpha=0,05$ dari data postes. Ber-dasarkan hasil perhitungan diperoleh $t_{\text {hitung }}>t_{\text {tabel }}$ $(2,064>1,669)$, sehingga dapat disimpulkan bahwa ada pengaruh yang signifikan terhadap hasil belajar siswa dengan menerapkan pendekatan pembelajaran kontekstual pada materi pokok Fluida Dinamis semester Genap kelas XI SMA Neger i9 Medan.

\section{PEMBAHASAN}

Hasil

penelitian menunjukkan bahwa ada pengaruh yang signifikan menggunakan pendekatan pembelajaran kontekstualterhadap hasil belajar fisika siswa pada materi pokok Fluida Dinamis di kelas XI IPA semester Genap SMA Negeri 9 Medan T.P 2012/2013. Hal ini ditunjukkan dengan perolehan nilai rata-rata postes sebesar 72,82 dengan standar deviasi 8,343. 
Sedangkan di kelas kontrol nilai rata-rata postes sebesar 68,23 dengan standar deviasi 9,94.

Berdasarkan

hasil perhitungan uji perbedaan nilai rata-rata postes kelas eksperimen dan kelas control diperoleh $\mathrm{t}$ hitung $=$ $2,064>t$ tabel $=1,669$, maka $\mathrm{H}_{0}$ ditolak dan terima $\mathrm{H}_{\mathrm{a}}$, sehingga diperoleh kesimpulan bahwa terdapat ada pengaruh pendekatan pembelajaran kontekstual terhadap hasil belajar siswa pada materi pokok Fluida Dinamis di kelas XI IPA semester I SMA Negeri 9 Medan T.P 2012/2013.

Dengan rata-rata nilai hasil belajar siswa (postes) pada kelas yangmeng-gunakan pendekatan kontekstual adalah 72,82 dengan nilai tertinggi 88,00 dan nilai terendah 56,00 serta nilai standar deviasianya adalah 8,34 , sedangkan pada kelas yang menggunakan pembelajaran konvensional diperoleh rata-rata nilai hasil belajar siswa (postes) adalah 68,23 dengan nilai tertinggi 84,00 dan terendah 48,00 serta dengan nilai standart deviasi adalah 9,94.

Berdasarkan perhitungan

Persentase hasil belajar siswa diperoleh peningkatan sebesar $6,73 \%$, sehingga dapat disimpulkan bahwa ada pengaruh pendekatan pembelajaran kontekstual terhadap hasil belajar siswa pada materi pokok Fluida Dinamis di kelas XI IPA semester Genap SMA Negeri 9 Medan T.P 2012/2013 sebesar 6,73 $\%$.

Faktor pertama yang mempengaruhi lebih tingginya hasil belajar siswa pada kelas eksperimen terletak di awal pembelajaran (tahap 1) Dalam CTL, pembelajaran merupakan proses peng-aktifan pengetahuan yang sudah ada (activiting knowledge), artinya apa yang akan dipelajari tidak terlepas dari pengetahuan yang sudah dipelajari, dengan demikian pengetahuan yang akan diperoleh siswa adalah pengetahuan yang utuh yang dimiliki keterkaitan satu sama yang lain, sedangkan pada pembelajaran konvensional cenderung guru memulai pelajaran kurang mengaitkan dengan pelajaran sebelumnya.

Faktor kedua karakteristik pemahaman pengetahuan, artinya pengetahuan yang diperoleh bukan untuk dihafal tapi untuk dipahami dan diyakini, misalnya dengan cara meminta tanggapan dari yang lain tentang pengetahuan yang diperolehnya dan berdasarkan tanggapan tersebut baru pengetahuan itu dikembangkan, sedangkan pada pembelajaran konvensional pengetahuan baru cenderung sebatas pemahaman tanpa ada tanggapan dari yang lain. Faktor ketiga karakteristik mempraktekkan pengetauan dan pengalaman tersebut, artinya pengetahuan dan pengalaman yang diperolehnya diaplikasikan dalam kehidupan siswa, sehingga tampak perubahan perilaku manusia, sedangkan pada pembelajaran konvensional pada kelas kontrol hanya pada materi tertentu saja diaplikasikan dalam kehidupan siswa. Faktor keempat dalam melakukan refleksi terhadap strategi pengembangan pengetahuan. Hal ini dilakukan sebagai umpan balik untuk proses perbaikan dan penyempurnaan strategi, sedangkan pada pembelajaran konvensional hal ini jarang dilakukan (Sanjaya W, 2006). Disamping kelebihan yang diberikan, dalam penelitian yang 
dilaksanakan juga memiliki beberapa ke-lemahan antara lain : kondisi kelas sulit dikontrol karena kesempatan diskusi dalam proses pembelajaran memberi peluang bagi siswa untuk ribut sehingga kelas mudah ricuh. Alokasi waktu yang digunakan kurang mencukupi. Peneliti mengalami kesulitan ketika menerapkan komponen inquiri karena siswa cenderung pasif.

\section{KESIMPULAN}

Simpulan dari penelitian ini adalah: Terdapat perbedaan hasil belajar yang signifikan antara siswa yang dibelajarkan dengan menerapkan pendekatan pembelajaran kontekstual dan pembelajaran konvensional. Pengaruh peningkatan hasil belajar sebesar $6,73 \%$ dengan menggunakan pendekatan pembelajaran kontekstual terhadap hasil belajar siswa pada materi pokok Fluida dinamis di kelas XI IPA semester genap T.P 2012/2013.

\section{SARAN}

Saran untuk penelitian selanjutnya adalah: (1) Peneliti selanjutnya diharapkan agar dapat menggunakan alokasi waktu semaksimal mungkin sehingga tiap tahap dari pelaksanaan pendekatan pembelajaran kontekstual dapat dilaksnakan semaksimal mungkin. (2) Peneliti selanjutnya agar dapat meminta bantuan kepada guru lain untuk dapat manertibkan siswa pada saat diskusi kelompok berlangsung.
DAFTAR PUSTAKA

Arikunto, S., (2011), Dasar-dasar Evaluasi Pendidikan Edisi Revisi,, Penerbit Bumi Aksara, Jakarta.

Asrina, L., (2009), Pengaruh Pendekatan Pembelajaran Kontekstual Terhadap Hasil Belajar Fisika pada Materi Pokok Zat dan Wujudnya di Kelas V II SMP Negeri 3 Kisaran Tahun Ajaran 2009/2010., Skripsi, FMIPA, Unimed, Medan.

Johnson, E.B.,(2007), Contextual Teaching and Learning, Menjadikan Kegiatan Belajar Mengajar Mengasyikan dan Bermakna, Mizan Learning Center ( MLC ), Bandung.

Sagala, S.., (2005),Konsep dan Makna Pembelajaran., Bandung. Penerbit Alfabeta.

Sanjaya, W., (2006). Pendekatan Pembelajaran Berorientasi Standar Proses Pendidikan, Penerbit Kencana, Jakarta.

Slameto,(2010),Belajar dan Faktorfaktor yang Mempengaruhinya, Penerbit Rineka Cipta, Jakarta.

Zendrato,G.P,Elisabeth, 2011. Pengaruh Pendekatan Kontekstual Terhadap Hasil Belajar Fisika pada Materi Pokok Kalor di KelasVII SMP SANTO THOMAS 3 Medan Tahun Ajaran 2011/2012., Skripsi, FMIPA, Unimed, Medan, 